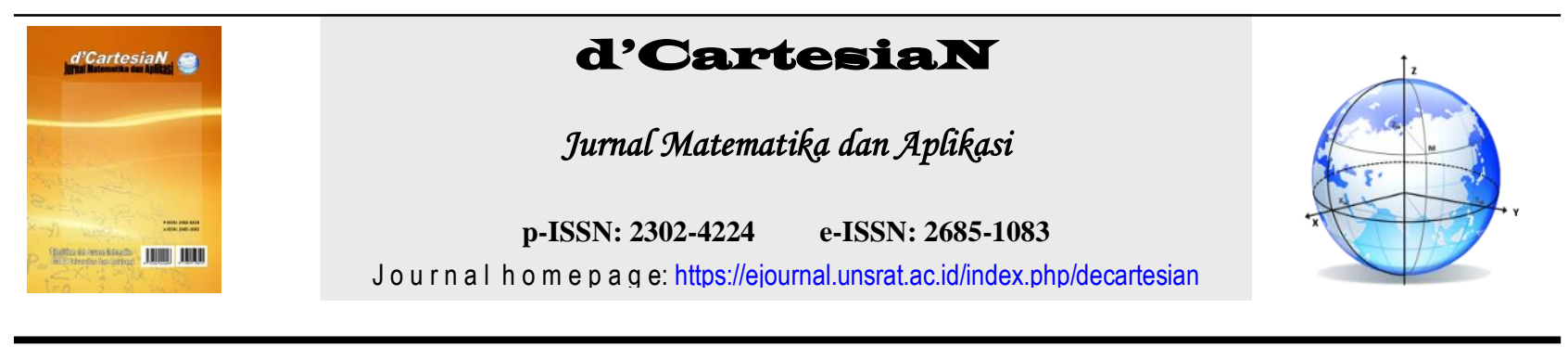

\title{
Prediksi Jumlah Penderita Demam Berdarah di Kabupaten Kepulauan Sangihe Dengan Menggunakan Model ARIMA Musiman
}

\author{
Jekir Venkil Dompas ${ }^{1}$, John S. Kekenusa ${ }^{{ }^{*}}$, Marline S. Paendong1 \\ ${ }^{1}$ Jurusan Matematika-Fakultas Matematika dan Ilmu Pengetahuan Alam-Universitas Sam Ratulangi Manado, Indonesia \\ *Corresponding author: johnskekenusa@unsrat.ac.id
}

\begin{abstract}
A B S T R A K
Penyakit Demam Berdarah Dengue adalah penyakit yang disebabkan oleh virus Dengue ditularkan kepada manusia melalui gigitan nyamuk Aedes Aegypti dan Aedes Albocpictus. Demam berdarah muncul sebagai kejadian luar biasa (KLB) sehingga mengakibatkan kepanikan di masyarakat karena beresiko menyebabkan kematian serta peyebarannya sangat cepat. Oleh sebab itu perlu dilakukan analisis tentang jumlah penderita demam berdarah yang akan datang. Metode ARIMA merupakan salah satu metode yang dapat digunakan dalam memprediksi jumlah penderita demam berdarah. Penelitian ini menggunakan data jumlah penderita demam berdarah bulanan di Kabupaten kepulauan Sangihe mulai dari bulan Januari 2011 hingga April 2019 untuk memprediksi jumlah penderita demam berdarah pada bulan Mei 2019 hingga April 2024. Prediksi Jumlah penderita DBD lima tahun berikutnya, terhitung mulai Mei 2019 sampai April 2024 sebanyak $1,1,1,3,1,0,1,4,1,4,1,1,1,2,1,0,2,3,1,0,3,0,2,3$, $1,1,1,3,2,1,2,3,1,3,1,1,2,3,2,1,2,3,2,1,3,1,3,3,2,2,2,3,3,1,2$, $3,2,3,2,2$ penderita
\end{abstract}

\section{A B S T R A C T}

Dengue Hemorrhagic Fever is a disease caused by the dengue virus which is transmitted to humans through the bites of the Aedes Aegypti and Aedes Albocpictus mosquitoes. Dengue fever appears as an extraordinary event (KLB), resulting in panic in the community because of the risk of causing death and its spread very quickly. Therefore, it is necessary to analyze the number of dengue fever sufferers in the future. The ARIMA method is a method that can be used in predicting the number of dengue fever sufferers. This study uses monthly data on the number of dengue fever sufferers in the Sangihe Islands Regency from January 2011 to April 2019 to predict the number of dengue fever sufferers from May 2019 to April 2024. Prediction of the number of dengue fever sufferers in the next five years, starting from May 2019 to April 2024 as much as 1, 1, 1, 3, 1, 0, 1, 4, 1, 4, 1, 1, 1, 2, 1, o, 2, 3, 1, o, 3, o, 2, 3, 1, 1, 1, 3, 2, 1, 2, 3, 1, 3, 1, 1, 2, 3, 2, 1, 2, 3, 2, $1,3,1,3,3,2,2,2,3,3,1,2,3,2,3,2,2$ sufferers

\section{INFO ARTIKEL:}

Diterima : 11 Juli 2020

Diterima setelah revisi : 29 Agustus 2020

Tersedia online : 4 Januari 2021

\section{Kata Kunci:}

Demam Berdarah

Sangihe

Time Series

ARIMA Musiman

\section{ARTICLE INFO:}

Received : 11 July 2020

Received after revision : 29 August 2020

Available online : 4 January 2021

\section{Keywords:}

dengue fever

Sangihe

Time Series

Seasonal ARIMA

\section{PENDAHULUAN}

Penyakit Demam Berdarah Dengue di Indonesia pertama kali dicurigai di Surabaya pada tahun 1968, tetapi konfirmasi pasti melalui isolasi virus baru dapat dilakukan pada tahun 1970. Sejak saat itu, penyakit DBD menyebar ke berbagai daerah sehingga sampai tahun 1980 seluruh provinsi di Indonesia kecuali Timor Timur telah terjangkit penyakit DBD. Sejak pertama kali ditemukan jumlah kasus cenderung meningkat secara signifikan baik dalam jumlah maupun luas wilayah yang terjangkit [1]. Salah satu cabang matematika yang membahas masalah demam berdarah di atas adalah statistik. Dalam Statistika dipelajari metode prediksi yang dapat diaplikasikan dalam kehidupan, Pada kasus DBD di atas dimana pada musim penghujan perkembangan nyamuk Aedes aegypty meningkat dan berakibat pada peningktan jumlah penderita demam berdarah, sehingga model prediksi yang sesuai adalah model ARIMA musiman 


\section{Time Series}

Analisis Time Series merupakan metode peramalan kuatitatif untuk menentukan pola pada data masa lampau yang dikumpulkan berdasarkan urutan waktu, yang disebut data time series. langkah penting dalam memilih suatu metode runtun waktu yang tepat adalah dengan mempertimbangkan jenis pola data, sehingga metode yang paling tepat adalah dengan pola data tersebut data diuji [2].

\subsection{ARIMA}

Model time series yang digunakan berdasarkan asumsi bahwa data time series tersebut stasioner artinya rata - rata dan varians suatu data time series konstan. Tapi seperti diketahui bahwa banyak data time series dalam ilmu ekonomi adalah tidak stasioner, jika data time sries tidak stasioner maka metode yang digunakan untuk membuat data stasioner yaitu dengan differencing untuk data yang tidak stasioner dalam rata - rata dan proses transformasi untuk data yang tidak stasioner dalam varians [3].

Secara umum persamaan model ARIMA adalah sebagai berikut [4]:

$$
\begin{aligned}
& W_{t}=\phi_{1} W_{t-1}+\phi_{2} W_{t-2}+\cdots+\phi_{p} W_{t-p}+\varepsilon_{t}-\varepsilon_{t}- \\
& \theta_{1} \varepsilon_{t-1}-\theta_{2} \varepsilon_{t-2}-\cdots-\theta_{p} \varepsilon_{t-q}
\end{aligned}
$$

Dimana:

$$
\begin{gathered}
W_{t}=Z_{t}-Z_{t-1} \\
\text { Sehingga, } \\
Z_{t}-Z_{t-1}=\phi_{1}\left(Z_{t-1}-Z_{t-2}\right)+\phi_{2}\left(Z_{t-2}-Z_{t-3}\right)+\cdots+ \\
\phi_{1}\left(Z_{t-p}-Z_{t-p-1}\right)+\varepsilon_{t}-\theta_{1} \varepsilon_{t-1}-\theta_{2} \varepsilon_{t-2}-\cdots- \\
\quad \theta_{q} \varepsilon_{t-q}
\end{gathered}
$$

\subsection{ARIMA Musiman}

Bentuk umum dari ARIMA telah ditunjukan sebelumnya dengan rumus:

$$
\begin{gathered}
Z_{t}-Z_{t-1}=\phi_{1}\left(Z_{t-1}-Z_{t-2}\right)+\phi_{2}\left(Z_{t-2}-Z_{t-3}\right)+\cdots+ \\
\phi_{1}\left(Z_{t-p}-Z_{t-p-1}\right)+\varepsilon_{t}-\theta_{1} \varepsilon_{t-1}-\theta_{2} \varepsilon_{t-2}-\cdots- \\
\theta_{q} \varepsilon_{t-q}
\end{gathered}
$$

Apabila menggunakan operator Backshift $\boldsymbol{B}$ maka model ARIMA dapat dituliskan sebagai berikut:

$$
\phi(\boldsymbol{B})(1-\boldsymbol{B})^{\boldsymbol{d}} Z_{\boldsymbol{t}}=\theta(\boldsymbol{B}) e_{\boldsymbol{t}}
$$

Pada kenyataannya ada beberapa data yang memperlihatkan pola musiman seperti jumlah pasien penderita demam berdarah, besarnya penjualan pakaian saat menjelang lebaran dan lain sebagainya. Ciri dari gerakan ini adalah gerakan yang mempunyai pola - pola tetap atau identik dari waktu - waktu dengan jangka waktu tertentu, gerakan tersebut dapat terjadi karena adanya peristiwa - peristiwa tertentu. Sehingga model umum untuk ARIMA musiman adalah:

Dimana:

$$
\Phi_{p}\left(\boldsymbol{B}^{s}\right)\left(1-\boldsymbol{B}^{s}\right)^{D} Z_{t}=\Theta_{Q}\left(\boldsymbol{B}^{s}\right) e_{\boldsymbol{t}}
$$

$\Phi_{p}\left(\boldsymbol{B}^{s}\right)=$ parameter AR musiman orde ke- $p$

$\Theta_{Q}\left(\boldsymbol{B}^{S}\right)=$ parameter MA musiman orde ke- $q$

$\Phi_{p}\left(\boldsymbol{B}^{s}\right)=1-\Phi_{1} \boldsymbol{B}^{s}-\Phi_{2} \boldsymbol{B}^{2 s}-\cdots-\Phi_{p} \boldsymbol{B}^{P S}$

$\Theta_{Q}\left(\boldsymbol{B}^{s}\right)=1-\Theta_{1} \boldsymbol{B}^{s}-\Theta_{2} \boldsymbol{B}^{2 s}-\cdots-\Theta_{Q} \boldsymbol{B}^{Q s}$

$s=$ musiman

\subsection{Kestasioneran Data}

Stasioner berarti bahwa tidak terdapat perubahan yang drastis pada data. Fluktuasi data berada disekitar suatu nilai rata - rata yang konstan, tidak tergantung pada waktu, dan varians dari fluktuasi tersebut. Bentuk visual dari plot data time series sering kali cukup meyakinkan para peramal bahwa data tersebut stasioner atau nonstasioner. Data time series dikatakan stasioner dalam rata - rata dan varians jika rata -ratanya tetap (tidak terdapat pola trend) dan lamda $=1$. Untuk mengatasi data deret waktu yang tidak stasioner dalam rata - ratanya, dapat dilakukan proses pembedaan terhadap data asli sedangkan jika data tidak stasioner terhadap varians dapat dilakukan transformasi.

\subsection{Proses Selisih}

Salah satu cara yang umum dipakai adalah metode pembedaan atau proses selisih (differencing). Proses selisih dilakukan jika data tidak stasioner dalam rata - ratanya. Metode ini dilakukan dengan cara mengurangi nilai data pada suatu periode dengan nilai data periode sebelumnya yang dapat dirumuskan sebagai berikut [5]:

$$
\Delta Y_{t}=Y_{t}-Y_{t-1}
$$

\subsection{Transformasi Box - Cox}

Transformasi Box-Cox dikenalkan dan dikembangkan oleh G. E. P Box dan D. R. Cox sekitar tahun 1964. Persamaan transformasi ini adalah [3]:

$$
T\left(X_{t)}=X_{t}(\lambda)=\frac{X_{t}^{\lambda}}{\lambda}\right.
$$

\subsection{Autocorrelation Function}

Autokorelasi adalah korelasi atau hubungan antara suatu variabel satu atau lebih periode sebelumnya dengan dirinya sendiri. Hubungan autokorelasi dengan lag nya dinamakan fungsi autokorelasi (ACF). Koefisien autokorelasi untuk lag $\mathrm{k}$ dari data runtun waktu dinyatakan berikut [6]:

Dimana :

$$
r_{k}=\rho_{k}=\frac{\sum_{t=1}^{n-k}\left(Z_{t}-\bar{Z}_{t}\right)\left(Z_{t+k}-\bar{Z}_{t}\right)}{\sum_{t=1}^{n}\left(Z_{t}-\bar{Z}_{t}\right)^{2}}
$$

$\rho_{k}:$ Koefisien korelasi pada lag-k $Z_{t}$ : Nilai variabel $Z$ pada waktu $\mathrm{t}$ $Z_{t+k}:$ Nilai variabel $\mathrm{Z}$ pada waktu $\mathrm{t}+\mathrm{k}$ $\bar{Z}_{t}$ : Nilai rata-rata variabel $Z_{t}$

\subsection{Partial Autocorrelation Function}

Autokorelasi parsial digunakan untuk mengukur tingkat keeratan antara Zt dan Zt-k apabila pengaruh dari lag waktu (time lag)1, 2, 3,...,k-1 dianggap terpisah. Koefisien autokorelasi parsial orde $\mathrm{m}$ didefinisikan sebagai koefisien autoregresif terakhir dari model AR (m). Menurut Wei (1990), rumus fungsi autokorelasi parsial ditulis dengan :

$$
\phi_{k+1, k+1}=\frac{\rho_{k+1}-\sum_{j=1}^{k-1} \phi_{k j} \rho_{k+1-j}}{1-\sum_{j=1}^{k-1} \phi_{k j} \rho_{j}}
$$

Dimana $: \rho_{k}=$ nilai autokorelasi lag- $k$

\subsection{Identifikasi Model}

Langkah awal dalam mengidentifikasi model adalah menentukan apakah data yang berkala yang akan digunakan bersifat stasioner atau tidak. Jika diketahui bahwa data tidak stasioner maka akan dilakukan penstasioneran terlebih dahulu dengan motode pembedaan. Stasioneritas terjadi pada sebuah data jika tidak terdapat peningkatan atau penurunan pada data. Data tetap berada pada sumbu horizontal 
sepanjang waktu. Dengan kata lain, frekuensi data berada disekitar suatu nilai rata - rata yang konstan, tidak tergantung pada waktu.

Setelah langkah awal dipenuhi, yaitu telah memperoleh data yang stasioner, maka langkah selanjutnya adalah menentukan bentuk dari model yang akan digunakan dengan cara membandingkan koefisien autokorelasi dan autokorelasi parsial dari data tersebut untuk dicoba dengan distribusi yang bersesuaian dengan model ARIMA musiman.

\subsection{Pendugaan Parameter}

Setelah menetapkan identifikasi model sementara, langkah selanjutnya adalah pendugaan parameter. Misalnya model ARIMA $(1,0,1)$ telah dipilih, maka model matematika dan bentuk peramalannya adalah:

$$
\begin{gathered}
Z_{t}=\phi_{0}+\phi_{1} Z_{t-1}+e_{t}-\theta_{1} e_{t-1} d a n \\
\hat{Z}=\phi_{0}+\phi_{1} Z_{t-1}-\theta_{1} e_{t-1}
\end{gathered}
$$

Dengan menggunakan persamaan peramalan, maka harus ditentukan nilai untuk $\phi_{1}$ dan $\theta_{1}$. Dimana nilai ini dapat ditentukan dengan menggunakan Software Minitab, yaitu dengan meminimumkan jumlah kuadrat nilai sisa sebagai kriteria untuk memilih nilai yang optimal.

\subsection{Uji Diagnostik}

Uji diagnostik adalah untuk memastikan apakah model yang dipilih sudah baik atau tidak, dengam menggunakan model sementara yang sementara dianggap paling cocok, maka nilai kesalahannya diselidiki. Hal ini dilakukan untuk menentukan kelayakan penaksiran parameter. Perlu diperhatikan bahwa model peramalan yang baik akan menghasilkan kesalahan yang berdistribusi random dengan rat - rata nol dan varians yang tetap. Jika pengujian diagnostik gagal, maka tahapan identifikasi, penaksiran parameter, dan uji diagnotik diulang kembali. Hal ini dilakukan sampai sebuah model yang cocok atau yang baik diperoleh. Setelah terpilih model dengan nilai parameter yang sesuai, maka model tersebut sudah dapat digunakan untuk meramalkan data pada waktu yang akan datang. Apabila pada suatu saat pola data time series berubah, maka penaksiran parameter dilakukan kembali atau model yang baru dicari kembali (Nainggolan,2009).

\subsection{Proses White Noise}

Proses White Noise didefinisikan sebagai urutan dari variable acak yang independen dan berdistribusi identik, disingkat dengan istilah i.i.d. Time Series $\left\{\varepsilon_{t}\right\}$ dinamakan white noise apabila rangkaiannya merupakan variabel acak yang independen dan berdistribusi identik, yang memenuhi (Wei,1990):

$E\left(\varepsilon_{t}\right)=\mu_{\varepsilon}$ konstan (diasumsikan dengan nol)

$\gamma(k)=E\left(Z_{t}-\mu\right)\left(Z_{t+k}-\mu\right)=0$ untuk semua $k \neq 1$ $\gamma(k)=\sigma^{2}$

\section{METODOLOGI PENELITIAN}

\subsection{Sumber Data}

Data diambil dari Dinas Kesehatan Kabupaten Kepulauan Sangihe yang berupa data bulanan jumlah penderita demam berdarah di Kabupaten Sangihe pada periode Januari 2011 sampai April 2019.

\subsection{Waktu dan Tempat Penelitian}

Penelitian dilaksanakan dari bulan Juni 2019 sampai bulan November 2019. Pengambilan data dilakukan di Dinas Kesehatan Kabupaten Kepulauan Sangihe dan penyusunan serta analisis data dilakukan di Laboratorium Statistika, Fakultas Matematika dan Ilmu Pengetahuan Alam, Universitas Sam Ratulangi Manado.

\subsection{Metode Analisis}

Langkah-langkah yang dilakukan untuk menganalisis dalam kajian ini adalah.

1. Pengumpulan Data

Data yang digunakan adalah data jumlah penderita demam berdarah di Kabupaten Sangihe yang diperoleh dari Dinas Kesehatan Kabupaten Kepulauan Sangihe.

2. Membuat plot data asli yang ada secara grafis.

3. Pengujian kestasioneran data

Jika diketahui data tidak stasioner dalam rata rata maka perlu dilakukan pembedaan (differencing). Apabila data tidak stasioner dalam varian maka dilakukan transformasi data. Jika data sudah stasioner maka dicari nilai ACF dan PACF dan merumuskan model umum.

4. Mencari parameter model dan menetapkan model sementara

5. Menguji apakah parameter tersebut signifikan dan layak untuk dijadikan model, jika tidak layak perlu dilakukan uji kesesuaian model dengan mencari alternative model yang lain

6. Menetapkan model terbaik untuk peramalan

7. Prediksi

Setelah model yang tepat ditemukan maka peramalan untuk satu periode atau beberapa periode yang akan datang dapat ditentukan.

\section{HASIL DAN PEMBAHASAN 4.1. Plot Data DBD}

Data jumlah penderita yang diperoleh dari Dinas Kesehatan Kabupaten Kepulauan Sangihe selama sembilan tahun terakhir ialah sebagai berikut:

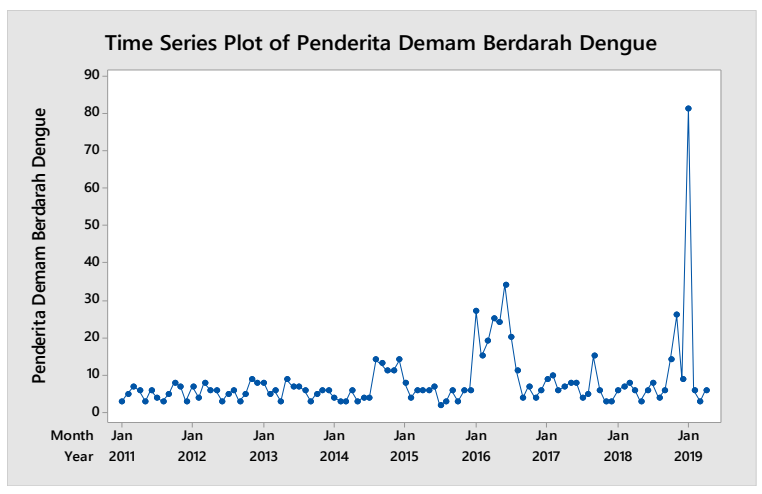

Gambar 1. Plot Deret Waktu ( Time Series Plot) Penderita DBD 
d'Cartesian: Jurnal Matematika dan Aplikasi, Vol. 9, No. 2 (September 2020): 126-132

Dari gambar 1 terlihat bahwa data belum stasioner karena adanya perubahan nilai tengah.

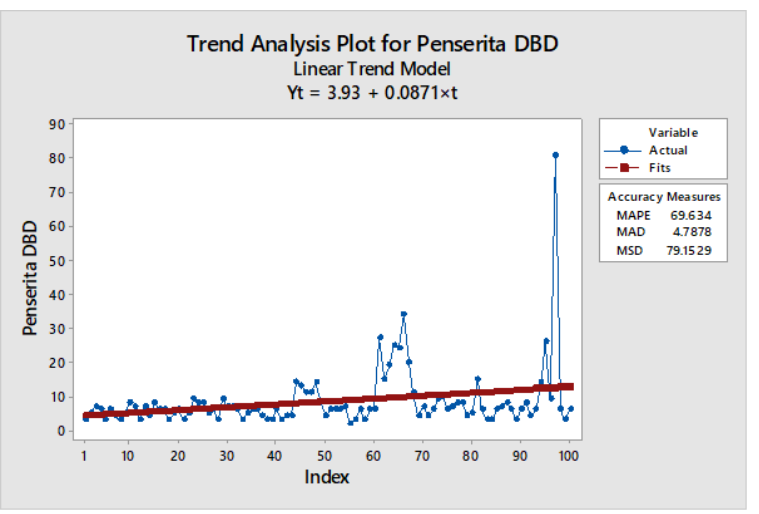

Gambar 2. Plot Trend Analysis data Penderita DBD

Ada 2 cara untuk menguji kestasioneran data yaitu perlu dilakukan Transformasi untuk melihat kestasioneran data dalam varians dan differencing untuk melihat kestasioneran data dalam rata - rata.

\section{Stasioner terhadap Varians}

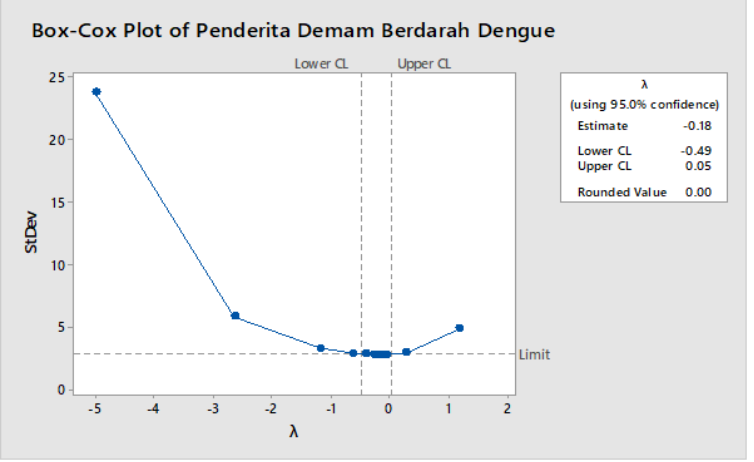

Gambar 3. Plot Transformai Pertama Penderita DBD.

Gambar 3, terlihat bahwa data untuk Tranformasi pertama belum stasioner terhadap varians.

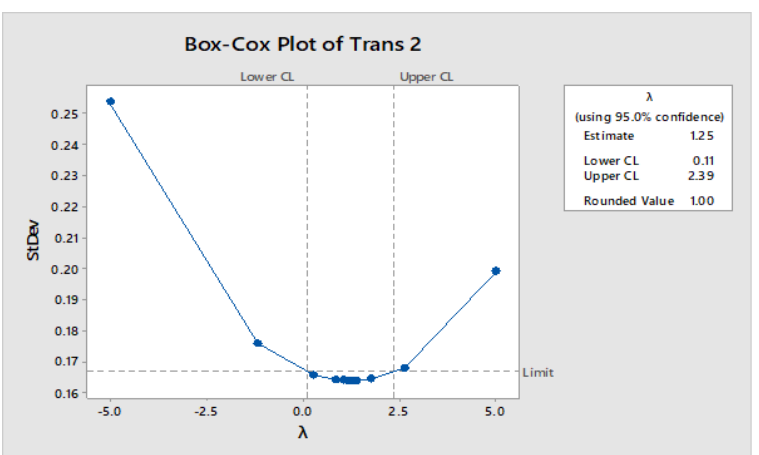

Gambar 4. Plot Transformasi Kedua Penderita DBD.
Gambar 4, terlihat bahwa data untuk Tranformasi kedua belum stasioner terhadap varians.

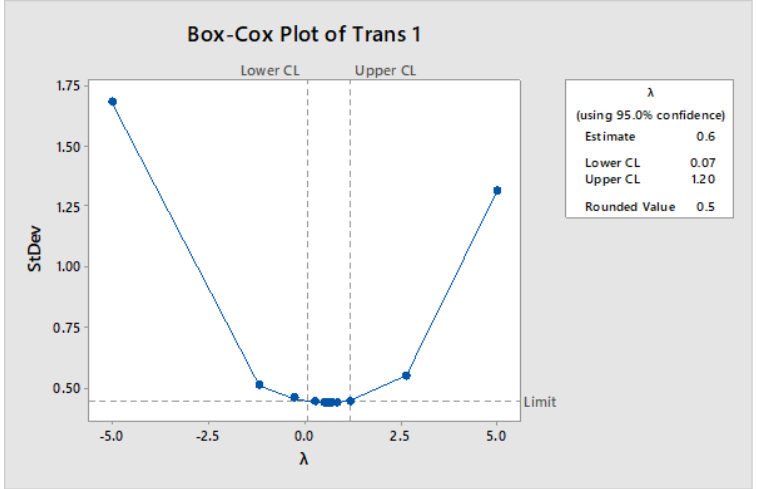

Gambar 5. Plot Tranformasi Ketiga Penderita DBD.

Gambar 5 terlihat bahwa data Transformasi ketiga sudah stasioner terhadap varians karena $\lambda=$ 1.00. Langkah selanjutanya melihat apakah data Penderita DBD stationer terhadap rataan.

2. Stasioner terhadap rataan.

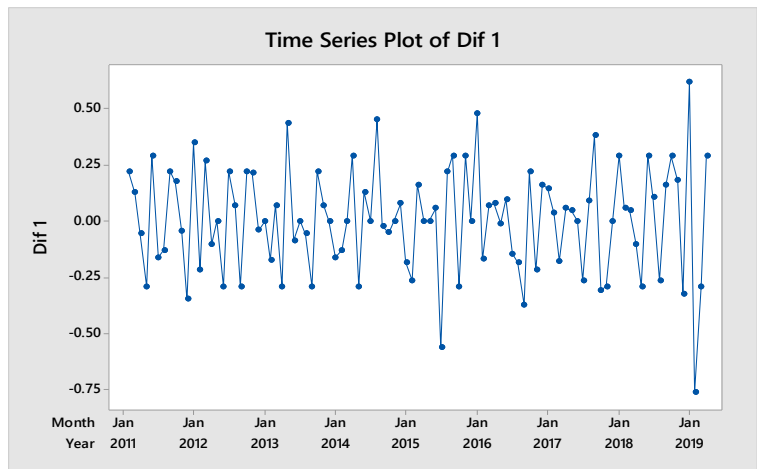

Gambar 6. Plot Differencing Pertama Penderita DBD.

Dari Gambar 6 terlihat bahwa data telah stasioner dan titik dari tiap nilai konstan terhadap nol. Setelah melakukan differencing (Pembedaan) pada pola musiman, plot ACF dan PACF harus dilihat kembali.

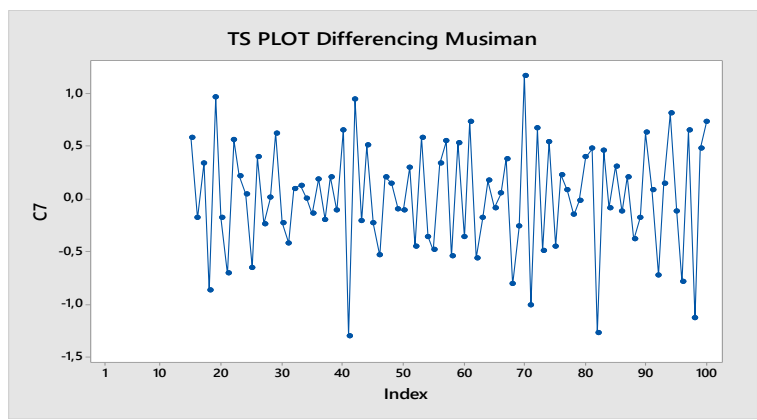

Gambar 7. TS Plot Hasil Pembedaan untuk Musiman. 


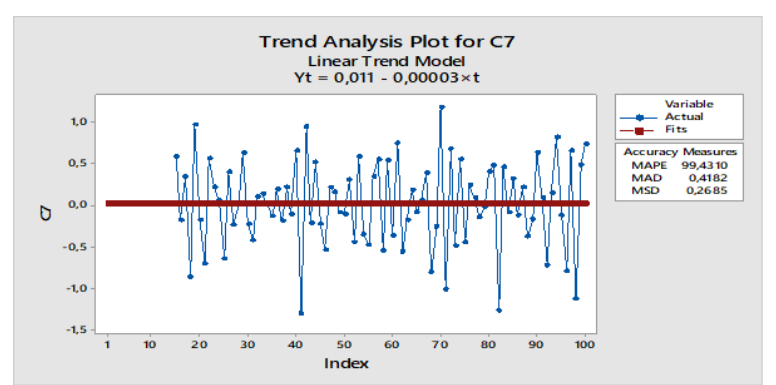

Gambar 8. Trend Plot Hasil Pembedaan untuk Musiman.

Pada gambar 8 terlihat bahwa data telah stasioner terhadap rataan, karena tidak ada trend naik atau pun turun.

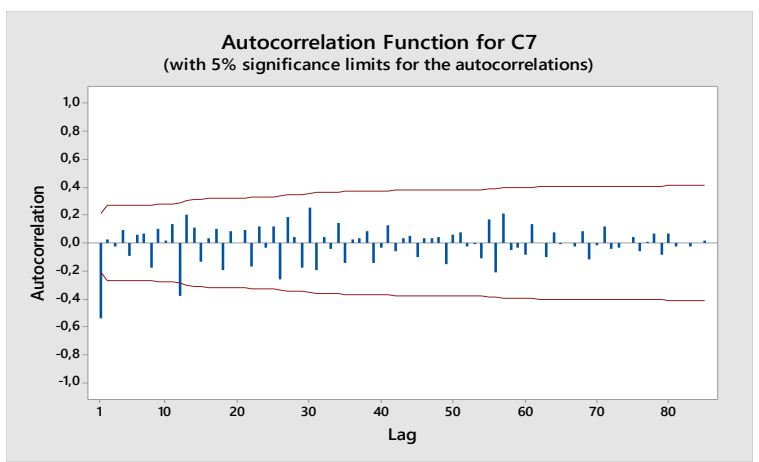

Gambar 9. Plot ACF Penderita DBD.

Dari gambar 9, terlihat $\mathrm{X}=\mathrm{Lag}$ dan $\mathrm{Y}=$ nilai Autocorrelation penderita demam berdarah untuk Moving Average (MA) non terdapat 1 lag yang keluar dari selang kepercayaan sedangkan untuk Moving Average (MA) musiman terdapat 1 yang keluar dari selang kepercayaan.

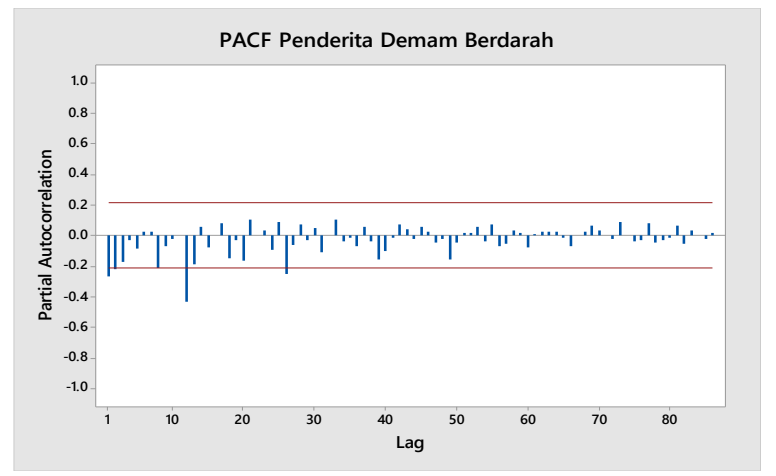

Gambar 10. Plot PACF Penderita DBD

Dari Gambar 10, terlihat $\mathrm{X}=\mathrm{Lag}$ dan $\mathrm{Y}=$ nilai Autocorrelation penderita demam berdarah. Untuk Autoregresive (AR) non musiman terdapat 1 lag yang keluar dari selang kepercayaan, sedangkan untuk Autoregresive (AR) musiman terdapat 2 lag yang keluar dari selang kepercayaan, sehingga dengan melihat lag yang keluar dari selang kepercayaan dapat kita tentukan nilai dari model tersebut yaitu AR(1) ,MA(1), SAR(2) dan SMA (1) dengan Differencing untuk non musiman $=1$ dan Differencing untuk pola musiman $=1$.

\subsection{Menduga Parameter Model}

Tabel 1. Pendugaan Parameter

\begin{tabular}{|c|c|c|}
\hline Model ARIMA & MSE & Parameter \\
\hline$(1,1,1)(2,1,1)^{12}$ & 0,1581 & $\begin{array}{c}\text { Tidak } \\
\text { Signifikan }\end{array}$ \\
\hline,$(1,1,1)(2,1,0)^{12}$ & 0,2021 & Signifikan \\
\hline$(1,1,1)(1,1,1)^{12}$ & 0,1970 & Signifikan \\
\hline$(1,1,1)(0,1,1)^{12}$ & 0,2685 & Signifikan \\
\hline$(1,1,1)(1,1,0)^{12}$ & 0,2677 & Signifikan \\
\hline
\end{tabular}

Dari Tabel 1, terlihat bahwa model ARIMA $(1,1,1)(1,1,1)^{12}$ adalah model yang layak digunakan untuk memperdiksi jumlah penderita DBD.

Hasil estimasi parameter model ARIMA dapat dilihat pada output di bawah ini.

\begin{tabular}{|c|c|c|c|c|c|}
\hline Type & & Coef & SE Coef & $\mathrm{T}$ & $\mathrm{P}$ \\
\hline $\mathrm{AR}$ & 1 & $-0,6648$ & 0,0944 & $-7,05$ & 0,000 \\
\hline SAR & 12 & $-0,7867$ & 0,1156 & $-6,81$ & 0,000 \\
\hline $\mathrm{MA}$ & 1 & 0,8941 & 0,1056 & 8,47 & 0,000 \\
\hline SMA & 12 & 0,6909 & 0,1450 & 4,76 & 0,000 \\
\hline Cons & Eant & 0,002583 & 0,002812 & 0,92 & 0,362 \\
\hline
\end{tabular}

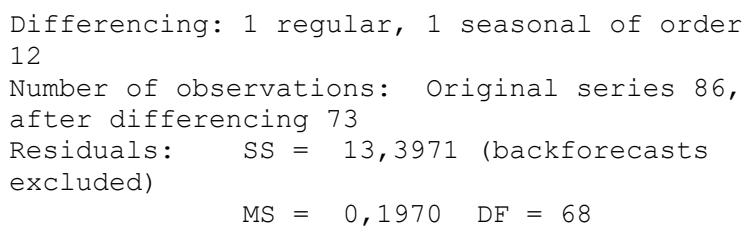

Dari output di atas terdapat 4 parameter. Tabel taksiran parameter menunjukan parameter $\phi_{1}=$ $-0,6648$, parameter $\Phi_{1}=-0,7867$, parameter $\theta_{1}=$ 0.8941 dan parameter $\Theta_{1}=0,6909$. Jika nilai $p$-value $<\alpha$ maka kesimpulannya seluruh parameter signifikan dalam model. Jadi persamaan modelnya adalah:

$$
\begin{gathered}
Z_{t}=\left(1+\phi_{1}\right) Z_{t-1}-\phi_{1} Z_{t-2}+\left(1+\Phi_{1}\right) Z_{t-12}- \\
\Phi_{2} Z_{t-24}+e_{t}-\theta_{1} e_{t-1}-\Theta_{1} e_{t-12}+\theta_{1} \Theta_{1} e_{t-12} \\
Z_{t}=(0,3352) Z_{t-1}+(0,6648) Z_{t-2}+(0,2133) Z_{t-12}+ \\
(0,7867) Z_{t-24}-(0,8941) e_{t-1}-(0,6909) e_{t-12}- \\
0,62 e_{t-12}
\end{gathered}
$$

\subsection{Pengujian Model}

Sebelum model tersebut digunakan untuk memprediksi perlu dilakukan pengujian kelayakan parameter dari model tersebut. Dari model di atas model terlihat telah signifikan pada taraf kepercayaan 0,05 sehingga semua parameter tersebut layak digunakan sebagai model Prediksi.

Untuk lebih meyakinkan bahwa model tersebut sesuai maka perlu dilakukan validasi model dengan data yang sudah ada.

Bulan Januari 2018 ialah 5 penderita sedangkan data riilnya 6 penderita, dan untuk bulan Februari 2018 sebanyak 4 penderita sedangkan data riilnya 7 penderita. 
Setelah mendapatkan model yang ditentukan untuk prediksi, maka akan dilakukan uji diagnosis pada data yang telah dianalisis sebagai berikut :

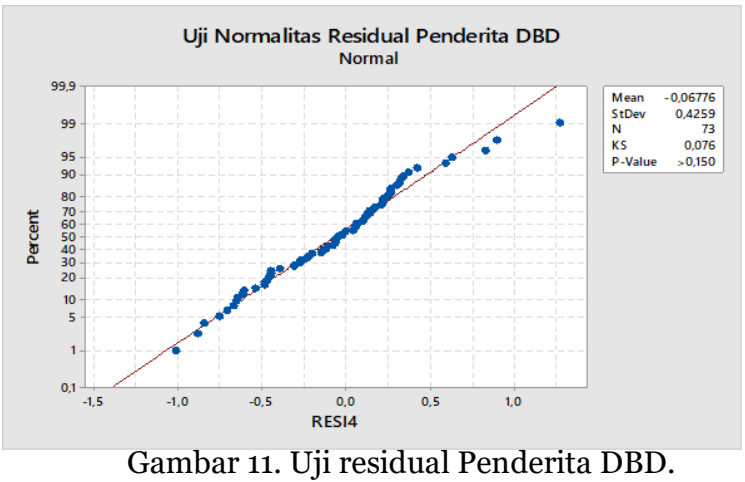

Dengan menggunakan uji normalitas Kolmogorov - Smirnov, dapat dilihat pada Gambar 11 bahwa titik - titik biru dalam grafik bergerak mendekati garis normal dengan $\mathrm{p}$-value $=0,150$ atau niainya lebigh besar dari 0,05 ( alpha atau tingkat signifikan pengujian) yang artinya telah berdistribusi normal dan memenuhi syarat white noise.

\subsection{Prediksi}

Hasil pemodelan telah signifikan dan memenuhi asumsi yang diisyaratkan, berarti model ARIMA $(1,1,1)(1,1,1)^{12}$ memuaskan dan berarti bisa dibuat prediksi data kedepan.

Tabel 2. Hasil Prediksi penderita DBD untuk Bulan Mei 2019 - April 2024

\begin{tabular}{|l|l|l|l|l|l|l|l|l|l|l|l|l|}
\hline & $\begin{array}{l}\text { Ja } \\
\mathrm{n}\end{array}$ & $\begin{array}{l}\mathrm{F} \\
\mathrm{e} \\
\mathrm{b}\end{array}$ & $\begin{array}{l}\mathrm{M} \\
\mathrm{ar}\end{array}$ & $\begin{array}{l}\mathrm{A} \\
\mathrm{pr}\end{array}$ & $\begin{array}{l}\mathrm{M} \\
\mathrm{ei}\end{array}$ & $\begin{array}{l}\mathrm{Ju} \\
\mathrm{ni}\end{array}$ & $\begin{array}{l}\mathrm{J} \\
\mathrm{ul} \\
\mathrm{i}\end{array}$ & $\begin{array}{l}\mathrm{A} \\
\mathrm{gt}\end{array}$ & $\begin{array}{l}\mathrm{S} \\
\mathrm{e} \\
\mathrm{p}\end{array}$ & $\begin{array}{l}\mathrm{O} \\
\mathrm{kt}\end{array}$ & $\begin{array}{l}\mathrm{N} \\
\mathrm{ov}\end{array}$ & $\begin{array}{l}\mathrm{D} \\
\mathrm{es}\end{array}$ \\
\hline $\begin{array}{l}20 \\
19\end{array}$ & - & - & - & - & 1 & 1 & 1 & 3 & 1 & 0 & 1 & 4 \\
\hline 20 & 1 & 4 & 1 & 1 & 1 & 2 & 1 & 0 & 2 & 3 & 1 & 0 \\
20 & & & & & & & & & & & & \\
\hline 20 & 3 & 0 & 2 & 3 & 1 & 1 & 1 & 3 & 2 & 1 & 2 & 3 \\
21 & & & & & & & & & & & & \\
\hline 20 & 1 & 3 & 1 & 1 & 2 & 3 & 2 & 1 & 2 & 3 & 2 & 1 \\
22 & & & & & & & & & & & & \\
\hline 20 & 3 & 1 & 3 & 3 & 2 & 2 & 2 & 3 & 3 & 1 & 2 & 3 \\
23 & & & & & & & & & & & & \\
\hline 20 & 2 & 3 & 2 & 2 & - & - & - & - & - & & - & - \\
24 & & & & & & & & & & & & \\
\hline
\end{tabular}

Dari hasil prediksi dapat dilihat grafik time series plot pada Gambar 12.

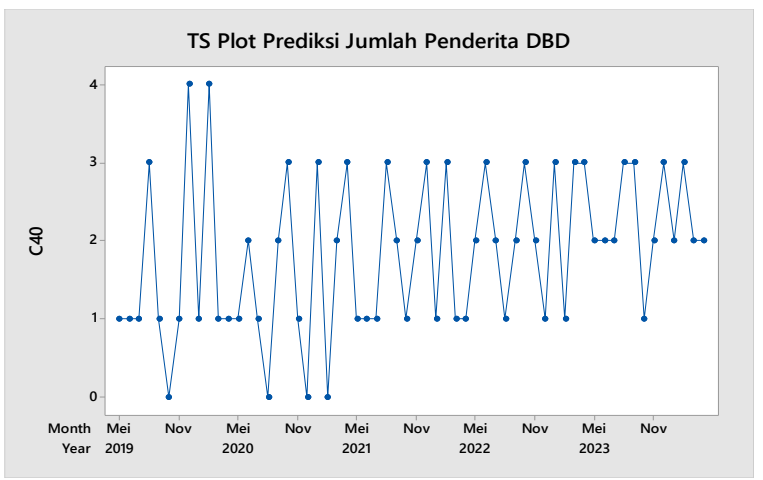

Gambar 12. Plot Hasil Prediksi

Grafik di atas menjelaskan bahwa jumlah penderita untuk bulan berikutnya mengalami penurunan dibandingkan dengan bulan - bulan sebelumnya, hal ini terjadi karena adanya kemungkinan faktor yaitu: semakin meningkatnya kesadaran masyarakat akan pentingnya menjaga kebersihan serta pelayanan kesehatan masyarakat yang semakin menyeluruh.

\section{KESIMPULAN}

1. Model yang tepat untuk memprediksi jumlah penderita demam berdarah di Kabupaten Kepulauan Sangihe adalah : model ARIMA musiman $(1,1,1)(1,1,1)^{12}$ dengan parameter AR(1) sebesar (0,6648), MA(1) sebesar (0.8941), SAR(12) sebesar (0,7867) dan untuk SMA(12) sebesar (0,6909). Sehingga persamaan untuk jumlah penderita DBD di Kabupaten Kepulauan Sangihe adalah:

$$
\begin{gathered}
Z_{t}=(0,3352) Z_{t-1}+(0,6648) Z_{t-2}+(0,2133) Z_{t-12}+ \\
(0,7867) Z_{t-24}-(0,8941) e_{t-1}-(0,6909) e_{t-12}- \\
0,62 e_{t-12}
\end{gathered}
$$

2. Prediksi jumlah penderita DBD untuk periode lima tahun berikutnya terhitung mulai bulan Mei 2019 - April 2024 adalah: 1, 1, 1, 3, 1, 0, 1, 4, 1, 4, $1,1,1,2,1,0,2,3,1,0,3,0,2,3,1,1,1,3,2,1,2,3,1,3$, $1,1,2,3,2,1,2,3,2,1,3,1,3,3,2,2,2,3,3,1,2,3,2$, $3,2,2$ penderita.

\section{DAFTAR PUSTAKA}

[1] Ginanjar, G 2008. DEMAM BERDARAH A Survival Guide. Bentang Pustaka, Yogyakarta

[2] Mulyono, S. 2004. Peramalan Harga Saham dan Nilai Tukar : Teknik Box-Jenkins. Ekonomi dan Keuangan Indonesia. Vol. XLVIII No.2.

[3] Mulyana, 2004. Buku Ajar Analisis Deret Waktu. Universitas Padjajaran FMIPA Jurusan Statistika, Bandung.

[4] Nainggolan, N. 2009. Model Time Series Heteroskedastik. Unpad Press. Bandung.

[5] Sartono, B. 2006. Modul Kuliah Pelatihan Time Series Analysis. IPB. Bogor

[6] Makridarkis, S., Wheelwright, S. C., \& McGee, V.E. 1999. Metode dan Aplikasi peramalan Jilid 1 Edisi Kedua. Terjemahan Ir, Untung S. Andriyanto dan Ir. Abdul Basith. Erlangga, Jakarta.

[7] Wei. S. 1990. Time Series Analysis. Addison Wesley Publishing Company.USA.

Jekir V. Dompas (jekirvenkildompas@gmail.com)

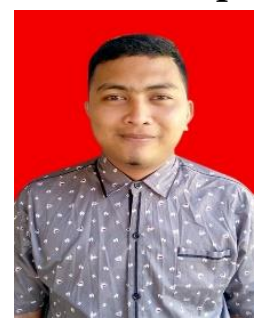
Lahir di Sangihe, Menempuh pendidikan tinggi Jurusan Matematika, FMIPA, Universitas Sam Ratulangi Manado pada tahun 2014. Tahun 2020 adalah tahun terakhir ia menempuh studi. Makalah ini merupakan hasil penelitian skripsinya yang dipublikasikan. 
John S. Kekenusa

(johnskekenusa@unsrat.ac.id)

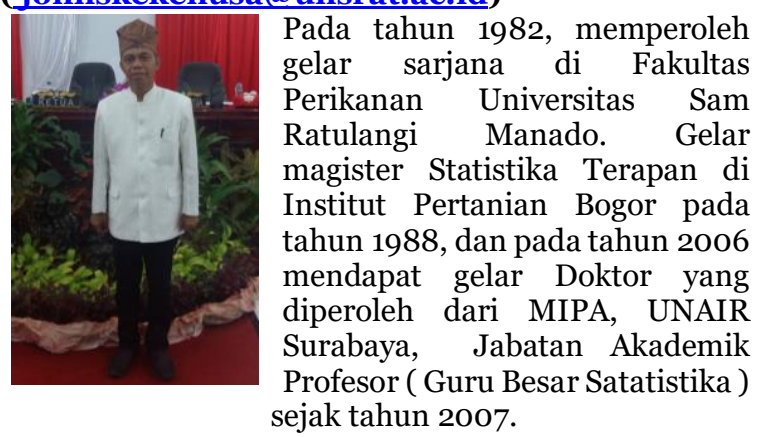

Marline S. Paendong

(MarlinePaendong@yahoo.com)

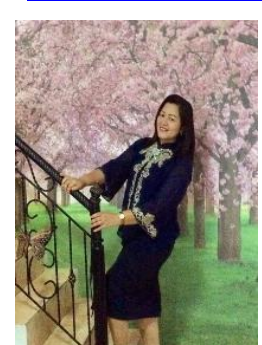

Pada tahun 1999, memperoleh gelar sarjana di Program Studi Matematika, Universitas Gadjah Mada. Gelar magister Sains di Institut Pertanian Bogor pada tahun 2006. Ia bekerja di UNSRAT di Program Studi Matematika FMIPA sebagai pengajar akademik tetap. 